\title{
CSANÁDPALOTÁN INDULT EL AZ ELSŐ ADÓSSÁGRENDEZÉSI ELJÁRÁS CSONGRÁD MEGYÉBEN*
}

\author{
Gyirán Zoltán ${ }^{1}$
}

A helyi önkormányzati rendszer eladósodását számos eszközzel igyekezett a jogalkotó megakadályozni, mellyel több tanulmány is foglalkozott a Közjavak c. folyóiratban. Ezek közül külön kiemelendö az adósságrendezéssel érintett települések elemzése, így például Szakoly esete. ${ }^{2}$

Az adósságrendezés célja a helyi önkormányzatok adósságrendezési eljárásáról szóló 1996. évi XXV. törvény (Har.) 1-\$-a értelmében az, hogy szabályozza a helyi önkormányzatok fizetöképességének helyreállitására irányuló eljárást, $s$ ennek során a hitelezöknek hatékony jogvédelmet biztositson, és az eljárás eredményeképpen pedig elösegitse a helyi önkormányzatok átgondolt, felelösségteljes gazdálkodását. Jelen tanulmány esetében egy olyan adósságrendezés kerül ismertetésre, amikor egy sajátos és egyedi kormányzati döntés következtében szenvedett csorbát az érintett önkormányzat.

\section{Az adósságrendezés előzményei}

$\mathrm{Az}$ egész rendszert érintő adósságrendezés keretében 2013 végén a Kormány átvállalta a település 67,5 millió forintos adósságát, azaz már ekkor, az adósságrendezési eljárás megindulását megelőzően sem volt zökkenőmentes a megye délkeleti csücskében, a román határ közelében található kisváros gazdálkodása.

A települést 2006 óta irányító polgármester 2017. február 23-án bekövetkezett halálát követően 2017. június 11 -én tette le az új polgármester az esküt. A gazdálkodás nehézségeiről az új polgármester első alkalommal a 2017. november 29-i rendkívüli ülésen tájékoztatta az önkormányzati képviselőket, majd a december 20-i soros ülésen részletesen taglalta a fizetésképtelenség bekövetkeztét.

Az új 2018-as év első ülésén az is kiderült, hogy már 2016-ban is gondok voltak a gazdálkodással, mivel 30 millió forint szállítói tartozást vittek át a következő költségvetési évre. Majd 2017 májusában már nem tudott eleget tenni adatszolgáltatási kötelezettségének sem az önkormányzat, ezért a Kincstár

\footnotetext{
* DOI 10.21867/KjK/2018.4.1.

${ }^{1}$ Dr. Gyirán Zoltán PhD, Geszterédi Közös Önkormányzati Hivatal jegyzője, a JOSZ SzabolcsSzatmár-Bereg Megyei Tagozatának elnöke

2 Gyirán Zoltán (2018): Mégis megtörténhet? - Szakoly Község Önkormányzatának adósság-rendezési eljárása. KÖZJAVAK, IV. évf., 2018/2. szám. 33-38. old.
} 
átmenetileg felfüggesztette a település normatív finanszírozását. ${ }^{3} \mathrm{Az}$ Önkormányzat ekkor az ASP-t kidolgozó céggel kötött szerződést a könyvelési feladatok ellátására, a beszámolók elkészítésére, mely 23 millió forintos rendkívüli kiadás az év végére több mint 50 millió forintos hiányt eredményezett.

A már említett 2018. január 2-i rendkívüli ülésen javaslatot tett a polgármester az adósságrendezési eljárás megindítására, előterjesztését azonban nem támogatták a települési képviselők, s egyúttal felkérték a polgármestert, hogy készítsen tájékoztatót és intézkedési tervet arról, hogy az Önkormányzat hogyan tudja rendezni a 90 napon túli tartozásait.

1. táblázat

\section{Csanádpalota Város Önkormányzatának adósságállománya 2018} januárjában

\begin{tabular}{|c|l|c|}
\hline Ssz. & Megnevezés & Tartozás összege $(\mathrm{Ft})$ \\
\hline 1. & Önkormänyzat & 54.177 .548 \\
\hline 2. & Közös Önkormányzati Hivatal & 632.589 \\
\hline 3. & Kelemen László Mủvelődési Ház & 297.882 \\
\hline 4. & Városi Könyvtár & 238.827 \\
\hline 5. & Napsugár Óvoda & 474.629 \\
\hline 6. & Alapszolgáltatási Központ & 3.864 .088 \\
\hline 7. & „Egyéb” tartozás & 10.296 .714 \\
\hline \multicolumn{2}{|c|}{ Összesen } & 69.982 .277 \\
\hline
\end{tabular}

Forrás: a szerző saját szerkesztése

Jól látható, hogy 2018. január 17-én közel 70 millió forint adóssága volt a helyhatóságnak, s ebből közel 8 millió forint volt a 90 napon túl lejárt tartozás. Mint ahogyan mindegyik eljárás estében, ebben az estben is lényegesnek tünhet feltárni az adósságrendezéshez vezető okokat. A különböző média-források azonban elég színes palettán részletezték az önkormányzati gazdálkodás hiányosságait, többek között okként említve meg a volt polgármester helytelen gazdálkodási gyakorlatát, a jegyzők és köztisztviselők fluktuációját, valamint az ASP rendszer elsajátításából következő nehézségeket. Éppen ezért elsősorban a hitelesnek tekinthető önkormányzati dokumentumok alapján próbáltam megvilágítani az adósságrendezés előzményeit.

A település reorganizációs programjában a jegyző azt rögzítette, hogy „az Önkormányzat eladósodásához és ezzel együtt a kényszerű adósságrendezési eljáráshoz több tényező együttes hatása járult hozzá, így: Az önkormányzatok által ellátott feladatok központi finanszírozási hányada folyamatosan csökkent,

3 https://www.napi.hu/magyar_gazdasag/nagy_gondban_csanadpalota.654193.html (letöltés dátuma: 2018. január 5.) 
azaz a normatív támogatások aránya az összes kiadáshoz képest csökkent, s egyre nagyobb önkormányzati hányadot igényelt, miközben a településen az adóerő-képességgel alacsony.

Az uniós projektek önrészéhez szükséges önkormányzati pénzeszközigény. A kötelezettség-állomány növekedési üteme, kezelhetősége az új számviteli nyilvántartási (ASP rendszer) bevezetésével egyidejűleg nehezen áttekinthetővé vált.

A jogszabály szerint elöírt nyilvántartások vezetésének hiánya, valamint az új számviteli nyilvántartási rendszer bevezetéséhez, alkalmazásához kapcsolódó nehézségek miatt, a gazdálkodás, a likviditási helyzet áttekintése nem volt naprakészen biztosított.

A pénzügyi területen történő folyamatos fluktuáció, szakemberhiány. A központi finanszírozásból az önkormányzat a személyi jellegű és szociális támogatások kifizetésein kívül szállítói és egyéb kötelezettségvállalásait csak folyamatos elmaradással, adósságállományának folyamatos növelése mellett tudta teljesíteni."

\section{Az adósságrendezési eljárás megindítása}

Végül a fenti indokokra is tekintettel az önkormányzat 2018. január 25-én nyújtotta be az adósságrendezési eljárás megindítására irányuló kérelmét, amely alapján a Szegedi Törvényszék 10.Apk.1/2018/5. számú végzésével 2018. február 12-én tette közzé Csanádpalota Város Önkormányzata adósságrendezésének megindításáról szóló végzését, s ezzel megindult az adósságrendezés. A törvényszék a budapesti székhelyü ABACUS-AUDIT Könyvvizsgáló, Felszámoló és Gazdasági Tanácsadó Kft.-t jelölte ki pénzügyi gondnoknak.

Mindezzel egyidejüleg a csanádpalotai polgármester a térség, azaz a Csongrád megyei 4. számú országgyülési egyéni választókerület képviselőjéhez fordult hathatós segítségben reménykedve. S nem is volt hiábavaló a kérése, hiszen a képviselő egy hódmezővásárhelyi lakossági fórumon bejelentette, hogy a Belügyminisztériumon és a Nemzetgazdasági Minisztériumon keresztül 72 millió forintot kap az önkormányzat. Ahogy fogalmaztak ,elég lehet arra, hogy Csanádpalota kimásszon a gödörből, és ami szintén fontos, a település így jó eséllyel nem veszíti el a 350 millió forintos, fejlesztésekre költhető Európai Uniós támogatást sem."

Hamarosan a forrásbiztosításáról szóló 1061/2018. Kormányhatározat is megjelent, melyben a Kormány az önkormányzat

\footnotetext{
Csanádpalota Város Önkormányzat reorganizációs programja, 1-2. (www.csanadpalota.hu)

5 https://makohirado.hu/2018/02/01/72-millio-forintot-kap-csodbe-jutott-csanadpalota/ (letöltés dátuma: 2018. február 1.)
} 
működőképességének biztosítása érdekében külön pályázat és kérelem benyújtása nélkül, támogatási előlegként 72,7 millió forint egyszeri támogatást nyújtott azzal a feltétellel, hogy az önkormányzat 2018. június 30-ig használhatja fel a március 9-én számlájára érkező támogatást. Ennek tudatában már megnyugodva írhatta le azt a polgármester: „Esetünkben, köszönhetően a vissza nem térítendő támogatásként kapott 72.700 .000 Ft-nak, minden hitelezői igény 100\%-ban kifizethető."” Majd a Szegedi Törvényszék 2018. július 6-án közzétette 10.Apk.1/2018/18. számú végzését, melyben az eljáró pénzügyi gondnok által 2018. május 25-én 11. sorszám alatt benyújtott egyezséget jóváhagyta, az eljárást pedig befejezetté nyilvánította.

2. táblázat

Csanádpalota Város Önkormányzata adósságrendezése során elfogadott egyezségi javaslat ${ }^{7}$

\begin{tabular}{|c|l|c|c|}
\hline Ssz. & $\begin{array}{l}\text { Hitelezői csoport megnevezése a Har. } \\
\text { szerint }\end{array}$ & $\begin{array}{l}\text { Követelés } \\
\text { összege (Ft) }\end{array}$ & $\begin{array}{l}\text { Kielégítés } \\
\text { aránya }\end{array}$ \\
\hline 1. & $\begin{array}{l}\text { A rendszeres személyi jellegü juttatások, } \\
\text { ideértve a közszolgálati, közalkalmazotti } \\
\text { jogviszony megszúnésekor járó } \\
\text { végkielégítést }\end{array}$ & 2.503 .587 & $100 \%$ \\
\hline 2. & $\begin{array}{l}\text { Az államot illetö követelések, a } \\
\text { visszafizetendő cél- és címzett támogatás, } \\
\text { tovább egyéb - visszatérítendő - } \\
\text { költségvetési támogatás összege }\end{array}$ & 12.357 .753 & $100 \%$ \\
\hline 3. & $\begin{array}{l}\text { A társadalombiztosítási tartozások, az adók } \\
\text { és az adók módjára behajtható } \\
\text { köztartozások }\end{array}$ & 1.039 .000 & $100 \%$ \\
\hline 4. & Egyéb követelések & 41.453 .584 & $100 \%$ \\
\hline \multicolumn{1}{|c}{ Összesen } & 57.353 .924 & $100 \%$ \\
\hline
\end{tabular}

Forrás: a szerző saját szerkesztése

\section{Az eljárás margójára}

A képviselö-testület időközben több mint egymilliárd forint föösszeggel megalkotta az önkormányzat 2018. évi válságköltségvetését, ${ }^{8} \mathrm{~s}$ elfogadta a május 4-én elkészült egyezségi javaslatot, ${ }^{9}$ valamint a reorganizációs tervet, az

${ }^{6}$ Csanádpalota Város Önkormányzat Képviselő-testülete 2018. május 14-i ülésének előterjesztése és jegyzőkönyve

7 Csanádpalota Város Önkormányzat Képviselő-testülete 2018. május 14-i ülésének jegyzőkönyve

8 4/2018. (III.22.) önkormányzati rendelet

${ }^{9}$ a 77/2018. (05.14.) képviselö-testületi határozatával 
egyezségi tárgyalás időpontját pedig május 22-ben határozta meg, mivel a hitelezői igények benyújtásának határideje május 14-én járt le.

Az egyezségi javaslat követelési összegének (57,3 millió forint) ismeretében egy érdekes kérdés merülhet fel, hogy mi lett a vissza nem térítendő támogatás (72,7 millió forint) és a hitelezői igény összegének különbözetét képező 15,4 millió forint sorsa? A választ a 2018. május 30-i képviselö-testületi ülés 1 . számú előterjesztésének (Csanádpalota jövőképe - egyeztetés az országgyülési képviselővel) negyedik oldalán találhatjuk: „a fennmaradó összeg müködési célra fordítható." Pozitív lehet így az adósságrendezés végkimenetele: öt hónapon belül befejeződött, a hitelezőket teljes mértékben kielégítették, sőt „müködési támogatásban” is részesült az önkormányzat. Viszont ez az utolsó történés kissé szembe megy a Mötv. 112. § (2) bekezdésével, mely rögzíti, hogy a helyi önkormányzat veszteséges gazdálkodásának következményei a helyi önkormányzatot terhelik, kötelezettségeiért a központi költségvetés nem tartozik felelösséggel. Különösen furcsa annak tudatában, hogy a megelőző 74 eljárás egyikének esetében sem szanálta a Kormány az adósságot. Jelen esetben egyetlen magyarázat látszik, mégpedig hogy a 2018. április 8-i országgyülési képviselőválasztás előtt kissé derogált volna, ha éppen a Miniszterelnökséget vezető miniszter választási körzetében áll egy önkormányzat adósságrendezés alatt. Éppen ezért „félre téve” a sarkalatos törvény vonatkozó rendelkezését, külön pályázat és kérelem benyújtása nélkül, támogatási előleg címszó alatt közel 73 millió forint egyszeri, vissza nem térítendő támogatásban részesítették a saját hibájából eljárás alatt álló önkormányzatot. Ez a kormányzati eljárás azonban megkérdőjelezi az adósságrendezési törvény létjogosultságát, hiszen úgy is ki lehet lábalni az adósságból, hogy nem csupán kifizeti az állam a felhalmozott adósságot, hanem még 15 millió forintos ,jutalomban” is részesíti az önkormányzatot.

$$
\text { **** * }
$$

Végezetül, ha már oly sok kérdés megfogalmazódott az első Csongrád megyei adósságrendezési eljárással kapcsolatosan, még egy utolsó „költői gondolat”. Az Állami Számvevőszék - a 2011. évi LXVI. törvény rendelkezései alapján jelenleg utóellenőrzést tart a 2009. január 1. és 2015. június 30. közötti időszakban adósságrendezési eljárás alatt álló önkormányzatoknál, s amint az a közzétett jelentésekből látható, már eddig is számos jogszabálysértést tártak fel. Vajon a jövőben készül-e számvevőszéki jelentés a csanádpalotai adósságrendezésről, s ha készül, az mit fog tartalmazni? 


\section{Források jegyzéke:}

- Gyirán Zoltán (2018): Mégis megtörténhet? - Szakoly Község Önkormányzatának adósság-rendezési eljárása. KÖZJAVAK, IV. évf., 2018/2. szám. 33-38. old.

- 4/2018. (III.22.) önkormányzati rendelete a 2018. évi válságköltségvetésröl

- 77/2018. (05.14.) képviselö-testületi határozat az egyezségi javaslatról

- Csanádpalota Város Önkormányzat Képviselö-testülete 2018. május 14i ülésének előterjesztése és jegyzőkönyve

- Csanádpalota Város Önkormányzat reorganizációs programja, 1-2.

- https://www.napi.hu/magyar_gazdasag/nagy_gondban_csanadpalota.65 4193.html

- https://makohirado.hu/2018/02/01/72-millio-forintot-kap-csodbe-jutottcsanadpalotal 